\title{
MODIFIKASI METODE HOUSEHOLDER TANPA TURUNAN KEDUA DENGAN ORDE KONVERGENSI OPTIMAL
}

\author{
WARTONO, DASA ELRISKA \\ Program Studi Matematika, \\ Universitas Islam Negeri Sultan Syarif Kasim Riau, \\ Jl. H. R. Subrantas km 15 No. 155, Pekanbaru, Indonesia. \\ email : wartono@uin-suska.ac.id,dasa.elriska@gmail.com
}

\author{
Diterima 10 Februari 2021 Direvisi 9 Maret 2021 Dipublikasikan 29 April 2021
}

\begin{abstract}
Abstrak. Metode Householder merupakan metode iterasi berorde konvergensi tiga yang digunakan untuk menyelesaikan persamaan nonliner. Selain itu, metode Householder menggunakan tiga evaluasi fungsi pada setiap iterasinya dengan indeks efisiensi sebesar $3^{1 / 3} \approx 1,4422$. Artikel ini membahas modifikasi metode Householder berparameter real $\lambda$ menggunakan deret Taylor orde dua. Selanjutnya, turunan kedua direduksi menggunakan deret Taylor orde dua dan menambahkan satu parameter real $\theta$. Hasil kajian menunjukkan bahwa metode iterasi baru mempunyai orde konvergensi empat untuk $\lambda=1$ dan $\theta=1$ dan melibatkan tiga evaluasi fungsi dengan indeks efisiensinya sebesar $4^{1 / 3} \approx 1.5874$. Simulasi numerik diberikan untuk menguji performasi metode iterasi tersebut yang meliputi jumlah iterasi dan nilai mutlak fungsi dengan menggunakan enam fungsi real. Ukuran-ukuran performasi dari metode iterasi baru dibandingkan dengan metode Newton, metode Newton-Steffensen, metode Householder dan metode Newton Ganda. Hasil simulasi numerik menujukkan bahwa metode iterasi baru mempunyai performasi yang lebih baik dibandingkan dengan metode iterasi lainnya.

Kata Kunci: Indeks efisiensi, metode Householder, orde konvergensi, persamaan nonlinier, simulasi numerik
\end{abstract}

\section{Pendahuluan}

Persoalan yang paling sering dijumpai pada persamaan nonlinier adalah menyelesaikan persamaan nonlinear dalam bentuk

$$
f(x)=0 .
$$

Hampir sebagian besar persamaan nonlinier merupakan representasi matematis dari fenomena-fenomena pada bidang sains, teknik dan rekayasa [5]. Hal ini mengakibatkan penyelesaian secara analitik sangat sulit diperoleh. Oleh karena itu, penyelesaian

*penulis korespondensi 
alternatif yang paling sering dilakukan adalah menggunakan penyelesaian secara numerik dalam bentuk perhitungan komputasi secara berulang yang bersifat iteratif. Metode penyelesaian seperti ini biasanya dikenal dengan nama metode iterasi.

Salah satu metode iterasi dengan algoritma sederhana yang digunakan untuk menyelesaikan persamaan nonlinier adalah metode Newton yang ditulis dalam bentuk

$$
x_{n+1}=x_{n}-\frac{f\left(x_{n}\right)}{f^{\prime}\left(x_{n}\right)} .
$$

Metode Newton merupakan metode iterasi yang dikonstruksi dari pemotongan deret Taylor orde satu dengan orde konvergensi kuadratik. Oleh karena metode Newton melibatkan tiga evaluasi fungsi untuk setiap iterasinya, maka indeks efisiensinya sebesar $2^{1 / 2} \approx 1.4142$.

Selain itu, pemotongan deret Taylor orde dua juga menghasilkan suatu metode iterasi berorde konvergensi tiga. Salah satu metode iterasi yang dikenal adalah metode iterasi Householder [10] yang ditulis dalam bentuk,

$$
x_{n+1}=x_{n}-\frac{2 f\left(x_{n}\right) f^{\prime}\left(x_{n}\right)}{2 f^{\prime}\left(x_{n}\right)^{2}-f\left(x_{n}\right) f^{\prime \prime}\left(x_{n}\right)} .
$$

Metode Householder merupakan metode iterasi berode konvergensi tiga dan melibatkan tiga evaluasi fungsi pada setiap iterasinya, sehingga indeks efisiennya sebesar $3^{1 / 3} \approx 1.4422$.

Untuk meningkatkan orde konvergensinya, beberapa peneliti telah memodifikasi metode Householder dengan menggunakan berbagai macam bentuk, seperti: menyusun kembali metode iterasi Householder menjadi bentuk prediktor-korektor $[15,16,17]$, Householder ganda [2], maupun triple-householder [8,9,12]. Metode iterasi yang dihasilkan dari modifikasi householder ini masih bergantung kepada turunan kedua pada proses komputasinya. Pada beberapa kasus, penggunaan turunan kedua sangat sensitif terhadap perhitungan komputasi, sehingga keterlibatan turunan kedua sangat dibatasi.

Beberapa peneliti menggunakan berbagai pendekatan untuk menghasikan bentuk reduksi turunan kedua, seperti kesamaan metode iterasi [1,11,18,21], fungsi hiperbola [3], fungsi parabola [23], selisih terbagi [6], dan deret Taylor [13].

Pada artikel ini dikonstruksi sebuah metode iterasi yang dikembangkan dari metode Householder yang diberikan pada Persamaan (1.3) dengan menambahkan satu parameter real $\lambda$ dan deret Taylor orde dua [4]. Selanjutnya turunan kedua yang muncul pada metode iterasi tersebut direduksi dengan menggunakan bentuk eksplisit turunan kedua dalam $x_{n}$ yang dihasilkan dari deret Taylor orde dua [13]. Untuk memperbesar peluang meningkatnya orde konvergensi metode iterasi, bentuk eksplisit turunan kedua juga diberi satu parameter real $\theta$.

Selanjutnya, untuk menguji performasi metode iterasi yang telah diperoleh, dilakukan simulasi numerik dengan menentukan banyaknya iterasi dan evaluasi fungsi, orde konvergensi yang dihitung secara komputasi (computational order of convergence atau COC), dan nilai mutlak fungsi pada iterasi ke- $n$. Pada simulasi numerik, metode iterasi diimplementasikan untuk menghitung akar-akar pendekatan dengan 
menggunakan enam fungsi real. Terakhir, dilakukan pebandingan indikator performasi, yaitu jumlah iterasi dan nilai mutlak fungsi pada iterasi ke- $n$ dari metode iterasi tersebut dengan empat metode iterasi lainnya.

\section{Landasan Teori}

\subsection{Deret Taylor}

Untuk mendukung proses konstruksi metode iterasi dan perhitungan komputasi pada simulasi numerik, penulis menggunakan teorema deret Taylor sebagai berikut.

Teorema 2.1. [7] Misalkan $f(x)$ adalah fungsi terdiferensialkan sebanyak $(n+1)$ pada interval terbuka $D$ untuk $n \geq 0$, dan misalkan $x, a \in D$, maka

$$
f(x)=f(a)+f^{\prime}(a)(x-a)+\frac{f^{\prime \prime}(x)}{2 !}(x-a)^{2}+\cdots+\frac{f^{n}(a)}{n !}(x-a)^{n}+R_{n}(x),
$$

dengan

$$
R_{n}(x)=\frac{f^{(n+1)}(\xi)}{(n+1) !}(x-a)^{n+1},
$$

untuk $a<\xi<x$.

\subsection{Akar Persamaan Nonlinier dan Orde Konvergensi}

Definisi 2.2. [14] Asumsikan bahwa $f(x)$ dan derivatif-derivatifnya $f^{\prime}(x), f^{\prime \prime}(x)$, $\ldots, f^{M}(x)$ adalah fungsi yang terdefinisi dan kontinu pada suatu selang di $x=\alpha$, maka dikatakan bahwa $f(x)=0$ mempunyai sebuah akar berode $M$ di $x=\alpha$ jika dan hanya jika

$$
f(\alpha)=0, f^{\prime}(\alpha)=0, f^{\prime \prime}(\alpha)=0, f^{M-1}(\alpha)=0, \operatorname{danf}^{M}(\alpha) \neq 0
$$

Misalkan sebuah akar berode $M$, untuk $M=1$ dan $M=2$, maka akarnya masing-masing biasa disebut akar sederhana dan akar ganda.

Selanjutnya, jika $\alpha$ adalah akar sederhana dari $f(x)=0$, maka suatu metode iterasi yang berode konvergensi dua akan konvergen dengan akurasi dua kali untuk setiap iterasi berikutnya. Untuk itu, berikut ini diberikan definisi kelajuan orde konvergensi dari suatu metode iterasi.

Definisi 2.3. [14] Misalkan $\left\{x_{n}\right\}_{n=0}^{\infty}$ adalah sebuah barisan iterasi, maka $\left\{x_{n}\right\}_{n=0}^{\infty}$ dikatakan konvergen ke $\alpha$ dengan orde konvergensi $p$ jika

$$
\lim _{n \rightarrow \infty} \frac{\left|x_{n+1}-\alpha\right|}{\left|x_{n}-\alpha\right|^{p}}=c,
$$

dengan $c$ adalah konstanta galat asimptotik.

Definisi 2.4. [14] Misalkan $e_{n}=x_{n}-\alpha$, maka hubungan

$$
e_{n+1}=c e_{n}^{p}+O\left(e_{n}^{p+1}\right),
$$

disebut persamaan galat, dan $p$ adalah orde konvergensi metode iterasi. Jika $p=1$ dan $p=2$, maka barisan $x_{n}$ masing-masing dikatakan konvergen linear dan kuadratik ke $\alpha$. 
Selain bergantung kepada orde konvergensi, performasi suatu metode iterasi juga bergantung kepada banyaknya evaluasi fungsi yang digunakan pada setiap iterasinya, yang biasanya disebut indeks efisiensi. Berikut ini diberikan definisi indeks efisiensi.

Definisi 2.5. [20] Misalkan d adalah banyaknya evaluasi fungsi yang digunakan pada pada setiap iterasi dari suatu metode iterasi berorde konvergensi p, maka indeks efisiensinya ditulis

$$
I=p^{1 / d}
$$

\subsection{Metode Iterasi Berode Konvergensi Tiga}

Sebuah ide pendekatan yang dikemukakan oleh Householder untuk menyelesaikan persamaan nonlinear yang ditulis dalam bentuk,

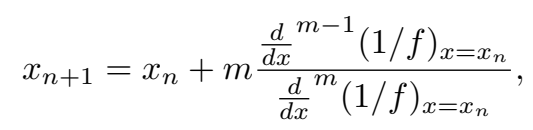

dengan $m=1,2, \cdots, k$. Metode iterasi (2.7) mempunyai orde konvergensi sebesar $(m+1)$ dan menggunakan evaluasi fungsi sebanyak $(m+1)$, sehingga berdasarkan Persamaan (2.6) indeks efisiensinya sebesar $(m+1)^{1 /(m+1)}$.

Untuk $m=2$, maka Persamaan (2.7) menjadi

$$
x_{n+1}=x_{n}+2 \frac{\frac{d}{d x}(1 / f)_{x=x_{n}}}{\frac{d^{2}}{d x}(1 / f)_{x=x_{n}}} .
$$

atau

$$
x_{n+1}=x_{n}-\left(1+\frac{f\left(x_{n}\right) f^{\prime \prime}\left(x_{n}\right)}{2 f^{\prime}\left(x_{n}\right)-f\left(x_{n}\right) f^{\prime \prime}\left(x_{n}\right)}\right) \frac{f\left(x_{n}\right)}{f^{\prime}\left(x_{n}\right)} .
$$

Persamaan (2.9) dikenal dengan nama metode iterasi Householder. Metode iterasi tersebut mempunyai orde konvergensi tiga dan melibatkan tiga evaluasi fungsi $f\left(x_{n}\right), f^{\prime}\left(x_{n}\right)$, dan $f^{\prime \prime}\left(x_{n}\right)$ sehingga indeks efisiennya sebesa $3^{1 / 3} \approx 1,4422$.

\section{Pembahasan}

\subsection{Modifikasi Metode Householder}

Pandang kembali metode Householder [10] dengan menambahkan satu parameter real $\lambda$ dalam bentuk

$$
x_{n+1}=x_{n}-\frac{2 f\left(x_{n}\right) f^{\prime}\left(x_{n}\right)}{2 f^{\prime}\left(x_{n}\right)^{2}-\lambda f\left(x_{n}\right) f^{\prime \prime}\left(x_{n}\right)} .
$$

Langkah pertama untuk mengkonstruksi metode iterasi adalah dengan ekspansi $f(x)$ menggunakan deret Taylor orde dua di persekitaran $x_{n}$, dalam bentuk

$$
\left.f(x)=f\left(x_{n}\right)+f\right]\left(x_{n}\right)\left(x-x_{n}\right)+\frac{f^{\prime \prime}\left(x_{n}\right)}{2 !}\left(x-x_{n}\right)^{2} .
$$


Misalkan $x_{n+1}$ adalah akar pendekatan persamaan nonlinier pada iterasi ke$(n+1)$, maka dengan menggunakan Persamaan (3.2) ekspansi $f\left(x_{n+1}\right)$ dalam bentuk

$$
\left.f\left(x_{n+1}\right)=f\left(x_{n}\right)+f\right]\left(x_{n}\right)\left(x_{n+1}-x_{n}\right)+\frac{f^{\prime \prime}\left(x_{n}\right)}{2 !}\left(x_{n+1}-x_{n}\right)^{2} .
$$

Oleh karena $x_{n+1}$ sangat dekat dengan akar persamaan nonlinier $\alpha$, maka $f\left(x_{n+1}\right) \approx$ 0 sehingga Persamaan (3.3) dapat diubah dalam bentuk

$$
x_{n+1}-x_{n}=-\frac{f\left(x_{n}\right)}{f^{\prime}\left(x_{n}\right)}-\frac{\left(x_{n+1}-x_{n}\right)^{2}}{2} \frac{f^{\prime \prime}\left(x_{n}\right)}{f^{\prime}\left(x_{n}\right)} .
$$

Selanjutnya $x_{n+1}$ pada ruas kanan Persamaan (3.4) diganti dengan Persamaan (3.1), sehingga Persamaan (3.4) dapat ditulis kembali menjadi

$$
x_{n+1}=x_{n}-\frac{f\left(x_{n}\right)}{f^{\prime}\left(x_{n}\right)}-\frac{2 f\left(x_{n}\right) f^{\prime}\left(x_{n}\right)^{2} f^{\prime \prime}\left(x_{n}\right)}{\left(2 f^{\prime}\left(x_{n}\right)^{2}-\lambda f\left(x_{n}\right) f^{\prime \prime}\left(x_{n}\right)\right)^{2}} .
$$

Persamaan (3.5) merupakan modifikasi varian metode iterasi Householder yang menggunakan tiga evaluasi fungsi untuk setiap iterasinya. Selain itu, metode iterasi masih memuat turunan kedua, yang mana pada beberapa kasus penggunaan turunan kedua tidak dapat direduksi. Oleh karena itu, untuk menghindari penggunaan turunan kedua, maka bentuk eksplisit ekspansi deret Taylor orde dua digunakan untuk mereduksi turunan kedua pada Persamaan (3.5).

Untuk menentukan bentuk eksplisit turunan kedua, pertimbangkan ekspansi deret Taylor orde dua terhadap $f\left(y_{n}\right)$ di persekitaran $x_{n}$ dengan mengabaikan sukusuku selanjutnya, yang ditulis dalam bentuk

$$
f\left(y_{n}\right) \approx f\left(x_{n}\right)+f^{\prime}\left(x_{n}\right)\left(y_{n}-x_{n}\right)+\frac{f^{\prime \prime}\left(x_{n}\right)}{2 !}\left(y_{n}-x_{n}\right)^{2} .
$$

Dari Persamaan (3.6), maka diperoleh bentuk eksplisit untuk $f^{\prime \prime}\left(x_{n}\right)$ dalam bentuk

$$
f^{\prime \prime}\left(x_{n}\right) \approx-2 \frac{-f\left(y_{n}\right)+f\left(x_{n}\right)+f^{\prime}\left(x_{n}\right)\left(y_{n}-x_{n}\right)}{\left(y_{n}-x_{n}\right)^{2}} .
$$

Bentuk eksplisit turunan kedua yang diberikan pada Persamaan (3.7) memuat $y_{n}$. Untuk mensubstitusi $y_{n}$, selanjutnya pertimbangkan kembali $y_{n}$ yang berasal dari metode Newton dengan satu parameter real $\theta$ dalam bentuk

$$
y_{n}=x_{n}-\theta \frac{f\left(x_{n}\right)}{f^{\prime}\left(x_{n}\right)} .
$$

Selanjutnya, dengan mensubstitusikan Persamaan (3.8) ke Persamaan (3.7), diperoleh bentuk eksplisit turunan kedua dengan parameter real

$$
f^{\prime \prime}\left(x_{n}\right)=\frac{2\left(f\left(y_{n}\right)-f\left(x_{n}\right)(1-\theta)\right) f^{\prime}\left(x_{n}\right)^{2}}{\theta^{2} f\left(x_{n}\right)^{2}} .
$$

Substitusikan kembali bentuk eksplisit turunan kedua pada Persamaan (3.9) ke Persamaan (3.5) dan dengan menyederhanakannya, maka Persamaan (3.5) menjadi

$$
x_{n+1}=x_{n}-\left(1+\frac{\theta^{2} f\left(x_{n}\right)\left(f\left(y_{n}\right)+f\left(x_{n}\right)(\theta-1)\right)}{\left(\lambda\left(f\left(y_{n}\right)+f\left(x_{n}\right)(\theta-1)\right)-\theta^{2} f\left(x_{n}\right)\right)^{2}}\right) \frac{f\left(x_{n}\right)}{f^{\prime}\left(x_{n}\right)} .
$$


Persamaan (3.10) merupakan modifikasi metode Householder tanpa turunan dengan dua parameter real $\lambda$ dan $\theta$ dan menggunakan tiga evaluasi fungsi pada setiap iterasinya yaitu $f\left(x_{n}\right), f\left(y_{n}\right)$ dan $f^{\prime}\left(x_{n}\right)$. Metode iterasi tersebut termasuk dalam kategori metode iterasi dua titik.

\subsection{Analisis Konvergensi}

Metode iterasi yang diberikan pada Persamaan (3.10) melibatkan tiga evaluasi fungsi. Selanjutnya, pada sub-bagian ini akan dibuktikan orde konvergensi dari metode iterasi tersebut. Parameter $\lambda$ dan $\theta$ yang terdapat pada metode iterasi memberikan peluang untuk meningkatkan orde konvergensi dengan mengganti nilai-nilai parameter dengan bilangan real.

Berikut ini akan dibuktikan orde konvergensi dari metode iterasi yang diberikan pada Persamaan (3.10).

Teorema 3.1. Misalkan $f: D \subset \mathbb{R} \rightarrow \mathbb{R}$ adalah fungsi yang mempunyai turunan pada interval D. Selanjutnya, asumsikan bahwa $\alpha$ adalah akar sederhana dari $f(x)=0$, dan misalkan $x_{0}$ adalah nilai tebakana awal yang cukup dekat di persekitaran $\alpha$, maka orde konvergensi Persamaan (3.10) adalah empat untuk $\lambda=1$ dan $\theta=1$ yang memenuhi persamaan galat berikut

$$
e_{n+1}=\left(2 c_{2}^{3}-c_{2} c_{3}\right) e_{n}^{4}+O\left(e_{n}^{5}\right)
$$

Bukti. Misalkan $\alpha$ adalah akar sederhana $f(x)$, maka $f(\alpha)=0$. Asumsikan bahwa $x_{n}=\alpha+e_{n}$, maka ekspansi $f(x)$ di persekitaran $\alpha$ untuk $x=x_{n}$ diberikan oleh

$$
f\left(x_{n}\right)=f^{\prime}(\alpha)\left(e_{n}+c_{2} e_{n}^{2}+c_{3} e_{n}^{3}+c_{4} e_{n}^{4}+O\left(e_{n}^{5}\right)\right),
$$

dengan

$$
c_{j}=\frac{1}{j !} \frac{\left.f^{(} j\right)(\alpha)}{f^{\prime}(\alpha)}, j=2,3, \cdots
$$

Selanjutnya dengan cara yang sama, maka diperoleh $f^{\prime}\left(x_{n}\right)$ sebagai berikut

$$
f^{\prime}\left(x_{n}\right)=f^{\prime}(\alpha)\left(1+2 c_{2} e_{n}+3 c_{3} e_{n}^{2}+4 c_{4} e_{n}^{3}+5 c_{5} e_{n}^{4}+O\left(e_{n}^{5}\right)\right) .
$$

Berdasarkan Persamaan (3.12) dan Persamaan (3.13) diperoleh

$$
\frac{f\left(x_{n}\right)}{f^{\prime}\left(x_{n}\right)}=e_{n}-c_{2} e_{n}^{2}+2\left(c_{2}^{2}-c_{3}\right) e_{n}^{3}+\left(7 c_{2} c_{3}-4 c_{2}^{3}-3 c_{4}\right) e_{n}^{4}+O\left(e_{n}^{5}\right) .
$$

dan dengan menggunakan (3.14), maka Persamaan (3.8) menjadi

$$
y_{n}=\alpha+(1-\theta) e_{n}+\theta c_{2} e_{n}^{2}-\theta\left(2 c_{2}^{2}-2 c_{3}\right) e_{n}^{3}+\theta\left(4 c_{2}^{3}-7 c_{2} c_{3}+3 c_{4}\right) e_{n}^{4}+O\left(e_{n}^{5}\right) .
$$

Selanjutnya menggunakan deret Taylor diperoleh $f\left(y_{n}\right)$ yang ditulis

$$
\begin{aligned}
f\left(y_{n}\right)= & f^{\prime}(\alpha)\left((1-\theta) e_{n}+\left(\theta^{2}-\theta+1\right) c_{2} e_{n}^{2}+\left(\left(-2 \theta^{2}\right) c_{2}^{2}+\left(-\theta^{3}+3 \theta^{2}-\theta+1\right) c_{3}\right) e_{n}^{3}\right. \\
& \left.+\left(5 \theta^{2} c_{2}^{3}+\left(3 \theta^{3}-10 \theta^{2}\right) c_{2} c_{3}+3 \theta c_{4}\right) e_{n}^{4}+O\left(e_{n}^{5}\right)\right) .
\end{aligned}
$$


Berdasarkan Persamaan (3.12) dan Persamaan (3.16) diperoleh

$$
\begin{aligned}
f\left(y_{n}\right)+f\left(x_{n}\right)(\theta-1)= & f^{\prime}(\alpha)\left(\theta^{2} c_{2} e_{n}^{2}+\left(-2 \theta^{2} c_{2}^{2}-\theta^{2}(\theta-3) c_{3}\right) e_{n}^{3}\right. \\
& \left.+\left(\theta^{2}(3 \theta-10) c_{2} c_{3}+5 \theta^{2} c_{2}^{3}\right) e_{n}^{4}+O\left(e_{n}^{5}\right)\right)
\end{aligned}
$$

sehingga diperoleh

$$
\begin{gathered}
\frac{\theta^{2} f\left(x_{n}\right)\left(f\left(y_{n}\right)+f\left(x_{n}\right)(1-\theta)\right)}{\left(\lambda\left(f\left(y_{n}\right)+f\left(x_{n}\right)(\theta-1)\right) \theta^{2} f\left(x_{n}\right)\right)^{2}}=c_{2} e_{n}+\left((2 \lambda-3) c_{2}^{2}+(3-\theta) c_{3}\right) e_{n}^{2} \\
+\left(\left(3 \lambda^{2}-12 \lambda+8\right) c_{2}^{3}+(\theta(4-4 \lambda)+12 \lambda-14) c_{2} c_{3}+\frac{1}{\theta}(4 \theta-1) c_{4}\right) e_{n}^{3} \\
+\left(\left(4 \lambda^{3}-27 \lambda^{2}+50 \lambda-8\right) c_{2}^{4}+\left(\theta\left(-9 \lambda^{2}+28 \lambda+4\right)+\left(27 \lambda^{2}-92 \lambda+17\right)\right) c_{2}^{2} c_{3}\right. \\
\quad \frac{1}{\theta^{2}}\left(\lambda(16 \theta-4)+\left(-\theta^{2}-4 \theta+1\right)\right) c_{2} c_{4}+(\theta-3)(2 \theta \lambda-6 \lambda+1) c_{3}^{2} \\
\left.\quad+\frac{1}{\theta^{2}}(\theta-1) c_{5}\right) e_{n}^{4}+O\left(e_{n}^{5}\right) .
\end{gathered}
$$

Substitusikan Persamaan (3.18) ke Persamaan (3.10) dan dengan menggunakan $x_{n+1}=e_{n+1}+\alpha$ dan $x_{n}=e_{n}+\alpha$, maka Persamaan (3.10) menjadi

$$
\begin{aligned}
e_{n+1}= & \left((\theta-1) c_{3}+(1-\lambda) 2 c_{2}^{2}\right) e_{n}^{3}-\frac{1}{\theta}\left(\left(\theta\left(3 \lambda^{2}-14 \lambda+17\right)-8\right) c_{2}^{3}\right. \\
& \left.+\left(\theta^{2}(-4 \lambda+5)+12 \theta(\lambda-1)\right) c_{2} c_{3}\right) e_{n}^{4}+O\left(e_{n}^{5}\right) .
\end{aligned}
$$

Persamaan (3.19) memberikan informasi bahwa orde konvergensi dapat ditingkatkan dengan mengambil $\theta-1=0$ dan $1-\lambda=0$. Selanjutnya dengan mensubstitusikan kembali $\theta=1$ dan $\lambda=1$ ke Persamaan (3.19), maka diperoleh

$$
e_{n+1}=-c_{2}\left(c_{3}-2 c_{2}^{2}\right) e_{n}^{4}+O\left(e_{n}^{5}\right)
$$

Persamaan (3.20) merupakan persamaan galat dari metode iterasi (3.10). Berdasarkan uraian di atas, dapat dilihat bahwa metode iterasi pada Persamaan (3.10) memiliki orde konvergensi empat untuk $\lambda=1$ dan $\theta=1$, dan melibatkan tiga evaluasi fungsi yaitu $f\left(x_{n}\right), f^{\prime}\left(x_{n}\right)$ dan $f^{\prime}\left(y_{n}\right)$ dengan indeks efisiensinya sebesar $4^{1 / 3} \approx 1,5874$.

\subsection{Simulasi Numerik}

Pada bagian ini, simulasi numerik diberikan untuk menguji performasi metode iterasi (3.10) dengan mengaplikasikan persamaan iterasi ke dalam enam fungsi real. Ukuran-ukuran performasi yang diuji adalah orde konvergensi yang dihitung secara numerik (computational order of convergence atau COC), jumlah iterasi (IT) dan nilai mutlak fungsi. Selanjutnya ukuran-ukuran performasi metode iterasi baru (MH) dibandingkan antara metode iterasi yang diberikan pada Persamaan (3.10) dengan 
metode Newton (N) [20], metode Newton-Steffensen (NS) [19], metode Householder (H) [10], dan metode Newton Ganda (NG) [20].

Pada proses menentukan akar-akar pendekatan, perhitungan komputasi menggunakan perangkat lunak Maple 13 dengan 850 angka titik kambang dengan kriteria komputasi

$$
\left|x_{n+1}-x_{n}\right|<\epsilon,
$$

sedangkan untuk menghitung orde konvergensi secara komputasi di gunakan [22]

$$
C O C \approx \frac{\ln \left|\left(x_{n+2}-\alpha\right) /\left(x_{n} n+1-\alpha\right)\right|}{\ln \left|\left(x_{n+1}-\alpha\right) /\left(x_{n}-\alpha\right)\right|} .
$$

Adapun enam fungsi real yang digunakan pada simulasi numerik adalah sebagai berikut:

$f_{1}(x)=x e^{-x}-0,1, \quad \alpha=0,111832559158962964834$,

$f_{2}(x)=e^{x}-4 x^{2}, \alpha=4,30658472822069929834$,

$f_{3}(x)=\cos (x)-x, \alpha=0,739085133215160641655$,

$f_{4}(x)=(x-1)^{3}-1, \alpha=2,00000000000000000000$,

$f_{5}(x)=x^{3}+4 x^{2}-10, \alpha=1.36523001341409684576$,

$f_{6}(x)=e^{-x^{2}+x+2}-\cos (x+1)+x^{3}+1, \alpha=-1,00000000000000000000$.

Salah satu ukuran performasi suatu metode iterasi pada proses menghampiri akar persamaan nonlinear adalah banyaknya iterasi yang digunakan. Metode iterasi dikatakan lebih baik dibandingkan dengan metode iterasi lainnya, jika banyaknya iterasi yang digunakan lebih sedikit. Hal ini menyatakan bahwa metode iterasi mempunyai performa baik jika menggunakan iterasi dalam jumlah sedikit. Tabel 1 berikut menampilkan perbandingan jumlah iterasi dan banyak evaluasi fungsi yang digunakan dari setiap metode iterasi untuk $\epsilon=10^{-20}$.

Tabel 1. Perbandingan Jumlah Iterasi (IT) dan Evaluasi Fungsi untuk $\epsilon=10^{-20}$

\begin{tabular}{|c|r|c|c|c|c|c|c|c|c|c|c|}
\hline$f(x)$ & $x_{0}$ & \multicolumn{9}{|c|}{ Jumlah Iterasi } & \multicolumn{3}{|c|}{ Jumlah Evaluasi Fungsi } \\
\hline & & $\mathrm{N}$ & $\mathrm{NS}$ & $\mathrm{H}$ & $\mathrm{NG}$ & $\mathrm{MH}$ & $\mathrm{N}$ & $\mathrm{NS}$ & $\mathrm{H}$ & $\mathrm{NG}$ & $\mathrm{MH}$ \\
\hline$f_{1}(x)$ & $-0,2$ & 6 & 4 & 4 & 3 & 3 & 12 & 12 & 12 & 12 & 9 \\
& 0,3 & 5 & 4 & 3 & 3 & 3 & 10 & 12 & 9 & 12 & 9 \\
\hline$f_{2}(x)$ & 4,0 & 6 & 4 & 4 & 3 & 3 & 12 & 12 & 12 & 12 & 9 \\
& 4,5 & 5 & 3 & 3 & 3 & 3 & 10 & 9 & 9 & 12 & 9 \\
\hline$f_{3}(x)$ & 0,1 & 5 & 4 & 4 & 3 & 3 & 10 & 12 & 12 & 12 & 9 \\
& 1,5 & 5 & 3 & 4 & 3 & 3 & 10 & 9 & 12 & 12 & 9 \\
\hline$f_{4}(x)$ & 1,8 & 5 & 4 & 3 & 3 & 3 & 10 & 12 & 9 & 12 & 9 \\
& 3,0 & 7 & 5 & 4 & 3 & 4 & 14 & 15 & 12 & 12 & 12 \\
\hline$f_{5}(x)$ & 1,0 & 5 & 4 & 3 & 3 & 3 & 10 & 12 & 9 & 12 & 9 \\
& 2,0 & 6 & 4 & 4 & 3 & 3 & 12 & 12 & 12 & 12 & 9 \\
\hline$f_{6}(x)$ & $-1,5$ & 5 & 3 & 4 & 3 & 3 & 10 & 9 & 12 & 12 & 9 \\
& 2,0 & 5 & 3 & 4 & 3 & 3 & 10 & 9 & 12 & 12 & 9 \\
\hline
\end{tabular}


Tabel 2 menunjukkan orde konvergensi metode iterasi yang dihitung secara komputasi dengan menggunakan perbandingan galat mutlak sebagaimana yang diberikan pada Persamaan (3.22). Nilai COC pada Tabel 2 ditampilkan dengan menggunakan enam digit dan toleransi sebesar $10^{-20}$.

Tabel 2. Perbandingan COC untuk $\epsilon=10^{-20}$

\begin{tabular}{|c|r|c|c|c|c|c|}
\hline$f(x)$ & $x_{0}$ & $\mathrm{~N}$ & $\mathrm{NS}$ & $\mathrm{H}$ & $\mathrm{NG}$ & $\mathrm{MH}$ \\
\hline$f_{1}(x)$ & $-0,2$ & 2,000000 & 2,999999 & 3,000000 & 3,999161 & 3,999976 \\
& 0,3 & 2,000000 & 3,000000 & 3,000517 & 3,999720 & 3,999976 \\
\hline$f_{2}(x)$ & 4,0 & 2,000000 & 3,000001 & 3,000000 & 3,998865 & 3,996862 \\
& 4,5 & 2,000000 & 2,999536 & 2,999815 & 3,999954 & 3,999911 \\
\hline$f_{3}(x)$ & 0,1 & 1,999999 & 3,000000 & 3,000000 & 3,999417 & 3,997290 \\
& 1,5 & 2,000000 & 2,999448 & 3,000000 & 3,999967 & 3,999772 \\
\hline$f_{4}(x)$ & 1,8 & 1,999999 & 3,000000 & 3,001037 & 3,999588 & 4,000000 \\
& 3,0 & 2,000000 & 2,998820 & 2,999653 & 3,999989 & 3,999951 \\
\hline$f_{5}(x)$ & 1,0 & 2,000000 & 3,000000 & 3,001185 & 3,999716 & 3,999151 \\
& 2,0 & 2,000000 & 3,000000 & 3,000000 & 3,999284 & 4,000000 \\
\hline$f_{6}(x)$ & $-1,5$ & 2,000000 & 2,999023 & 3,000002 & 4,000130 & 4,000642 \\
& 0,0 & 2,000000 & 3,005972 & 3,000278 & 4,000141 & 4,001388 \\
\hline
\end{tabular}

Berdasarkan Tabel 2 menunjukkan bahwa orde konvergensi modifikasi metode Householder adalah empat. Informasi ini menguatkan hasil orde konvergensi yang diperoleh menggunakan ekspansi deret Taylor.

Selain menggunakan jumlah iterasi dan COC, ukuran performasi metode iterasi dapat dilihat dari nilai mutlak fungsi pada iterasi ke-n. Ukuran ini menunjukkan akurasi suatu metode iterasi pada toleransi tertentu. Pada kasus ini, nilai mutlak fungsi yang dihasilkan oleh metode iterasi dibatasi oleh toleransi sebesar $10^{-20}$. Perbandingan nilai mutlak fungsi dari beberapa metode iterasi diberikan pada Tabel 3.

Tabel 3 menunjukkan bahwa metode iterasi pada Persamaan (3.10) mempunyai akurasi yang lebih baik dibandingkan dengan metode iterasi lainnya untuk $\epsilon=$ $10^{-20}$. Hal ini menunjukkan bahwa secara umum, performasi metode iterasi tersebut lebih baik dibandingkan dengan metode lainnya.

\section{Kesimpulan}

Modifikasi metode Householder mempunyai orde konvergensi empat dan memerlukan tiga evaluasi fungsi pada setiap iterasinya untuk $\lambda=1$ dan $\theta=1$. Oleh karena itu, indeks efisiensinya adalah sebesar $4^{1 / 3} \approx 1.6578$. Selanjutnya, performasi metode baru di implementasikan pada enam fungsi bernilai real. Performasi dari metode baru tersebut yang meliputi: jumlah iterasi, nilai mutlak $f(x)$ dibandingkan dengan metode lainnya, seperti: metode Newton, Newton Steffensen, Householder, Newton ganda. Tabel 1, dan 3 menunjukkan bahwa secara umum, performasi 
Tabel 3. Perbandingan $\left|f\left(x_{n}\right)\right|$ dengan $\epsilon=10^{-20}$

\begin{tabular}{|c|r|c|c|c|c|c|}
\hline$f(x)$ & $x_{0}$ & $\mathrm{~N}$ & $\mathrm{NS}$ & $\mathrm{H}$ & $\mathrm{NG}$ & $\mathrm{MH}$ \\
\hline$f_{1}(x)$ & $-0,2$ & $3,085(\mathrm{e}-36)$ & $1,272(\mathrm{e}-45)$ & $2,775(\mathrm{e}-66)$ & $3,085(\mathrm{e}-36)$ & $2.677(\mathrm{e}-131)$ \\
& 0,3 & $1,073(\mathrm{e}-42)$ & $9,053(\mathrm{e}-54)$ & $3,515(\mathrm{e}-66)$ & $1,073(\mathrm{e}-42)$ & $2,098(\mathrm{e}-149)$ \\
\hline$f_{2}(x)$ & 4,0 & $5,025(\mathrm{e}-33)$ & $5,576(\mathrm{e}-42)$ & $2,110(\mathrm{e}-53)$ & $5,025(\mathrm{e}-33)$ & $2,668(\mathrm{e}-114)$ \\
& 4,5 & $3,191(\mathrm{e}-52)$ & $2,426(\mathrm{e}-66)$ & $5,246(\mathrm{e}-76)$ & $3,191(\mathrm{e}-52)$ & $4,259(\mathrm{e}-198)$ \\
\hline$f_{3}(x)$ & 0,1 & $2,034(\mathrm{e}-46)$ & $4,746(\mathrm{e}-58)$ & $3,968(\mathrm{e}-49)$ & $2,034(\mathrm{e}-46)$ & $1,674(\mathrm{e}-138)$ \\
& 1,5 & $3,760(\mathrm{e}-64)$ & $3,507(\mathrm{e}-80)$ & $1,149(\mathrm{e}-51)$ & $3,760(\mathrm{e}-64)$ & $2,942(\mathrm{e}-197)$ \\
\hline$f_{4}(x)$ & 1,8 & $2,866(\mathrm{e}-41)$ & $4,236(\mathrm{e}-52)$ & $2,857(\mathrm{e}-20)$ & $2,866(\mathrm{e}-41)$ & $1,522(\mathrm{e}-141)$ \\
& 3,0 & $4,644(\mathrm{e}-16)$ & $3,096(\mathrm{e}-20)$ & $6,391(\mathrm{e}-24)$ & $4,644(\mathrm{e}-16)$ & $1,559(\mathrm{e}-54)$ \\
\hline$f_{5}(x)$ & 1,0 & $3,982(\mathrm{e}-43)$ & $9,105(\mathrm{e}-55)$ & $1,502(\mathrm{e}-69)$ & $3,982(\mathrm{e}-43)$ & $4,367(\mathrm{e}-150)$ \\
& 2,0 & $1,236(\mathrm{e}-37)$ & $7,813(\mathrm{e}-48)$ & $4,660(\mathrm{e}-52)$ & $1,236(\mathrm{e}-37)$ & $1,378(\mathrm{e}-137)$ \\
\hline$f_{6}(x)$ & $-1,5$ & $5,738(\mathrm{e}-66)$ & $5,189(\mathrm{e}-92)$ & $1,526(\mathrm{e}-43)$ & $5,738(\mathrm{e}-66)$ & $1,294(\mathrm{e}-173)$ \\
& 2,0 & $1,926(\mathrm{e}-65)$ & $9,363(\mathrm{e}-73)$ & $6,391(\mathrm{e}-26)$ & $1,926(\mathrm{e}-65)$ & $5,941(\mathrm{e}-154)$ \\
\hline
\end{tabular}

metode iterasi baru lebih baik dibandingkan dengan metode iterasi lainnya.

\section{Daftar Pustaka}

[1] Alamsyah, Wartono, 2017, Modifikasi metode Chaucy tanpa turunan kedua dengan orde konvergensi empat, Jurnal Sains Matematika dan Statistika, 3(2): $59-66$.

[2] Ali, A., et. al., 2016, Dynamic of modified Householder's method, Science International, 28(2): 825 - 828 .

[3] Sholeh, B., Wartono, 2019, Modifikasi metode Weerakoon-Fernando dengan orde konvergensi empat, Jurnal Sains Matematika dan Statistika, 5(1): 133 - 140.

[4] Behl, R., Kanwar, V., 2013, Variants od Chebyshev's with optimal order of convergence, Tamsui Oxford Journal of Information and Mathematical Sciences, 29(1): $39-53$.

[5] Capra, S.C., Canale, R. P, 2006, Numerical Methods for Engineers, Mc Graw Hill, New York.

[6] Chun, C., 2007, Certain improvements of Chebyshev-Halley methods with accelerated fourth-order convergence, Applied Mathematics and Computation, 189: $597-601$.

[7] Epperson, J. F., 2013, An Introduction Numerical Methods and Analysis, John Wiley \& Sons, New Jersey.

[8] Hafiz, M. A., Bahgat, M. S. M., 2014, Three-step iterative method with eighteenth order convergence for solving nonlinear equations, International Journal of Pure and Applied Mathematics, 93(1): 85 - 94.

[9] Abdul-Hasan, N. Y., 2016, New predictor-corrector iterative method with twelfth-order convergence for solving nonlinear equations, American Journal of Applied Mathematics, 4(4): 175 - 180.

[10] Householder, A. S., 1970, The Numerical Treatment of a Single Nonlinear Equation, McGraw-Hill, New York. 
[11] Kansal, M., Kanwar, V., Bhatia, S., 2016, Optimized mean based second derivative-free families of Chebyshev-Halley type methods, Numerical Analysis and Applications, 9(2): 129 - 140.

[12] Khan, W. A., Noor, M. A., Rauf, A., 2013, Higher-order iterative methods by using Householder's method for solving certain nonlinear equations, Mathematical Sciences Letters, 2(2): 107 - 120.

[13] Li, Y., Zhang, P., Li, Y., 2010, Some new variant of Chebyshev-Halley methods free from second derivative, International Journal of Nonlinear Science, 9(2): $201-206$.

[14] Mathews, J. H., 1992, Numerical Methods for Mathematics, Science, and Engineering, Prentince-Hall International, Inc., New Jersey.

[15] Nazeer, W., Tanveer, M., Kang, S. M., Naseem, A., 2016, A new Householder's method free from second derivatives for solving nonlinear equatons and polynomiography, Journal of Nonlinear Science and Applications, 9: 998 - 1007.

[16] Noor, M. A., Gupta, V., 2007, Modified Householder iterative method free from second derivative for nonlinear equation, Applied Mathematics and Computation, 190: 1701 - 1706.

[17] Noor, K. I., Noor, M. A., Momani, S., 2007, Modified Householder iterative method for nonlinear equation, Applied Mathematics and Computation, 190: $1534-1539$.

[18] Putri, R, Y., Wartono, 2020, Modifikasi metode Schroder tanpa turunan kedua dengan orde konvergensi empat, AKSIOMA : Jurnal Matematika dan Pendidikan Matematika, 11(2): 240 - 251.

[19] Sharma, J. R., 2005, A composite third-order Newton-Steffensen method for solving nonlinear equation, Applied Mathematics and Computation, 169: 242 246.

[20] Traub, J. F., 1964, Iterative Methods for the Solution of Equations, Prentice Hall, Englewood Cliffs, New Jersey.

[21] Wartono, Agustiwari, R., Rahmawati, 2019, New modification of Behl's method free from second derivative with an optimal order of convergence, Indonesian Journal of Pure and Applied Mathematics, 1(2): 10 - 19.

[22] Weerakoon, S., Fernando, T. G. I., 2000, A variant of Newton's method with accelerated third-order convergence, Applied Mathematics Letters, 13: 87 - 93.

[23] Yu, X., Xu, X., 2012, A new family of Chebyshev-Halley like methods free from second derivative, Fixed Point Theory, 13(1): 319 - 325. 